\title{
Synthesis and Characterization of New Heterocyclic Compounds from 2, 5- dimercapto -1, 3, 4-Thiadiazole and Their Resins
}

Email: israaaldoori@yahoo.com

Received 22/9/2015

Accepted 20/12/2015

(c) (1) $(9)$

This work is licensed under a Creative Commons Attribution-NonCommercial-

NoDerivatives 4.0 International Licens

\begin{abstract}
:
In this research, a new 1, 3, 4-Thiadiazole derivatives have been synthesized by many heterocyclic reactions. Starting from (2, 5 - dimercapto -1, 3, 4-Thiadiazole) a variety of derivatives have been synthesis. Compound (1) was synthesized by the reaction of hydrazine hydrate with carbon disulphide in absolute ethanol. The compound (1) was reacted with 1,2-dibromoethane in presence of alkali ethanol to give the compound (2). The compound (3) was formed from the reaction of compound (2) with hydrazine hydrate. Schiff base (4) was obtained by reacting of compound (3) with the compound (p-hydroxybenzaldehyde) in absolute ethanol. A variety of phenolic Schiff base (Methylolic, Etheric, and Epoxy) derivatives have been synthesized. Methylolic derivative was synthesized by the reaction of Schiff base (4) with formaldehyde in tetrahydrofuran (THF). Etheric derivative was formed from the reaction of a methylolic Schiff base (5) with saturated alcohol (Methanol).Epoxy derivative was synthesized by the reaction of epichlorohydrine with etheric derivative (6) .The last step of this research was the preparation of a composite material from mixing the Epoxy resin derivative(7), $\mathrm{TiO}_{2}$ and morpholine via ring opening. All these derivatives were verified by using (FT-IR, UV) spectra photometer and ${ }^{1} \mathrm{H}-\mathrm{NMR}$ spectra. Also, these derivatives were characterized using elemental analysis (C.H.N.S) .
\end{abstract}

Key words: Synthesis, new heterocyclic compounds, 2, 5 - dimercapto -1, 3, 4Thiadiazole, their resins

\section{Introduction:}

$1,3,4$-Thiadiazole is one of the most important biochemical materials and it is one of the most popular isomers in the pharmaceutical and the industrial fields. The studies have shown that heterogeneous quintet rings (thiadiazole) have different activities. The first one 
who described 1, 3, 4-Thiadiazole was Fisher in 1882 , but the real nature of the ring system described for the first time in 1890 by Freund and Kuh [1]. They found when a substitution occur in locations $(2,5)$ of the Thiadiazole compound with two groups of thiol (SH) this will give a more power to the compound with a wide range of uses.2,5- disubstituted-1, 3, 4thiadiazole derivative has biological activities including anticancer [2] antifungal [3] anti-tubercular [4] and anti-inflammatory [5]. Schiff bases are used in a wide range of applications, in biological field [6], industrial applications such as anticorrosion material for steel and alloys, photo stabilizers for poly ethylene, and the methylolic derivatives of phenolic. Schiff bases are used in the production of industrial polymers, such as PVC [7]. Epoxy derivatives are poly ethers contain an epoxy groups at the end of the chain, known as oxiranes [8].These resins undergo polymerization reactions through their ring opening and their participation in a process known industrially as"curing", using hardeners such as the amine compounds.Epoxy resins are used in adhesives, coatings and composite materials $[9,10]$. The main problem of the epoxy resin is with the passage of time suffered from break covalent bonds for epoxy resins, by sun light, therefore the addition of additives inorganic like $\mathrm{TiO}_{2}$ and Zinc oxide to the epoxy derivative will absorb ultraviolet light in the range (300-400) nm strongly [11], leading to non-absorption of these rays by the epoxy molecules and active functional groups [12].

\section{Materials and Methods}

Melting points were determined on electro thermal capillary apparatus and were uncorrected; FT-IR spectra were recorded using solid $\mathrm{KBr}$ disc by testing Shimadzu (FT-IR 8300). Ultraviolet spectra were recorded using
Shimadzu (UV-Visible) within range (200-900) nm, the elements analysis of compounds (C.H.N.S) by using a Perkin-Elmer, RE 2400, measurement was made at College of Education for Pure Science (Ibn Al- Haitham), Baghdad University. ${ }^{1}$ H-NMR spectra were carried out in Al-al Bayt University (Jordan) operating at 300 $\mathrm{MHz}$ in DMSO-d6 as solvent with the TMS as internal standard. All the chemical materials and solvents were purchased from (Isotecinc, BDH and Merck) companies.

Preparation of Compound (1) [13]: ( 2, 5-dimercapto-1, 3, 4-thiadiazole)

A mixture of $(0.1 \mathrm{~mol}, 4.8 \mathrm{ml})$ hydr-azine hydrate $(80 \%)$ with carbon disulfide $(0.2 \mathrm{~mol}, 12 \mathrm{ml})$ in absolute ethanol $(20 \mathrm{ml})$ was prepared. The mixture was refluxed with stirring for (4hrs) until the $\mathrm{H}_{2} \mathrm{~S}$ emission stoppage.Then, the reaction mixture was cooled, filtered and recrystallized in distilled water.

Preparation of Compound [14]:(2,2-dimarcapto-bis-(1,3,4Thiadiazole)-5-disulfide Alkyl)

In absolute ethanol $(0.7 \mathrm{~g})$ from sodium hydroxide was dissolved with stirring for $(1 \mathrm{hr}) .(0.011 \mathrm{~mol}, 1.7 \mathrm{~g})$ of the compound (1) was dissolves in absolute ethanol $(7.26 \mathrm{ml})$. Then the first prepared solution was added to the second solution, the mixture was stirred for 10 minutes. Then $(0.005 \mathrm{~mol}, 0.5 \mathrm{ml})$ from 1, 2-dibromoethane was added slowly to this mixture and refluxed for (6hrs) and then the mixture was cooled at room temperature, filtered, and recrystallized in absolute ethanol.

Preparation of Compound (3)[15]: (2, 2-dihydrazino-bis-1,3,4- thiadiazole-5disulfide- ethane)

The compound (2) (0.01 mol, 3.2 g) was dissolved in absolute ethanol $(24.5 \mathrm{ml})$ then $(0.02 \mathrm{~mol}, 0.96 \mathrm{ml})$ of hydrazine hydrate $(80 \%)$ were added. The reaction mixture was refluxed for (6hrs), the emission of hydrogen sulfide 
$\left(\mathrm{H}_{2} \mathrm{~S}\right)$ was tested by lead paper, and then the mixture was cooled to room temperature, filtered, recrystallized from absolute ethanol.

\section{Preparation of Compound [16]:(Schiff Base)}

The compound (2, 2dihydrazino-bis-1, 3, 4-thiadiazole -5disulfide ethane) (1mol) with ( $2 \mathrm{~mol})$ of the compound ( $\mathrm{p}$-hydroxybenzaldehyde) were mixed in absolute ethanol $(40 \mathrm{ml})$, refluxed for (8hrs) then cooled, filtered and recrystallized in absolute ethanol.

\section{Preparation of Compound (Methylolic Derivative) [17]:}

Schiff Base (4) $(5.3 \mathrm{~g}, 0.01 \mathrm{~mol})$ and $(1.2 \mathrm{~g}, 0.04 \mathrm{~mol})$ of formaldehyde were mixed in THF $(75 \mathrm{ml})$, the reactants were mixed gently with $10 \%$ of alcoholic sodium hydroxide solution to keep the acidity of the solution at $\mathrm{pH}$ (9$10)$. The reaction mixture was refluxed at $(50-60){ }^{0} \mathrm{C}$ for (3hrs) the mixture then neutralized with $10 \%$ of alcoholic phosphoric acid. The mixture was filtered and recrystallized from (THF).

Preparation of Saturated Etheric Derivative (6)[18]:

The saturated alcohol (Methanol) $(0.8 \mathrm{~mol})$ with $(1 \mathrm{ml})$ of sulphuric acid were mixed at $(5){ }^{0} \mathrm{C}$, then $(0.2 \mathrm{~mol})$ of a Methylolic Schiff Base (5)was added gradually with stirring at room temperature for (1hr) with the rise of the temperature to the boiling point of the alcohol used. The reaction mixture was refluxed for (24hrs) then cooled, the mixture was neutralized with sodium hydroxide.The derivative was extracted using chloroform, recrystallized from chloroform, and then dried.

Preparation of Epoxy Derivative (7) [19]:

The epichlorohydrine $(24.5 \mathrm{ml}$, $0.31 \mathrm{~mol})$ was mixed with $(7.2 \mathrm{ml}$, $0.12 \mathrm{~mol})$ of butanol and (0.01mole) of an etheric derivative, for 15 mints at $(50){ }^{0} \mathrm{C}$, then gently added $(4 \mathrm{~g}, 0.1 \mathrm{~mol})$ of sodium hydroxide in two stages with a maintained temperature below $(65){ }^{0} \mathrm{C}$
.The mixing continues for (2hrs). After the first addition the aqueous layer was separated from the organic layer, then a second batch of sodium hydroxide added and mixed for (1hr) the aqueous layer were separated while the organic layer dried and recrystallized from (THF).

\section{Preparation of Resin (8) with Opening of the Ring [20]:}

The epoxy derivative $(0.01 \mathrm{~mol})$ was mixed with $(20 \mathrm{ml})$ of methanol, then $(1.74 \mathrm{ml}, 0.02$ mole) of morpholine was added, refluxed for $(72 \mathrm{hrs})$ then cooled, filtered and recrystallized from methanol

Preparation of Composite Material (9) from Epoxy Resin Derivative with Opening of the Ring [21]:

The Epoxy resin $(0.01 \mathrm{~mole})$ was mixed with Methanol $(20 \mathrm{ml})$, a weight ratios of $40 \%, 30 \%, 10 \%$ and $5 \%$ (of the resin weight used) of titanium dioxide $\left(\mathrm{TiO}_{2}\right)$ pigment will be added, with a continuous stirring, then $(1.74 \mathrm{ml}, 0.02$ mole) of morpholine was added, refluxed for $(72 \mathrm{hrs})$ the product was painted on a glass slide of quartz and left to dry for (7-10) days.

\section{Results and Discussion}

Compound (1) was prepared as shown in scheme (1).Some physical properties for this compound were listed in Table (1).

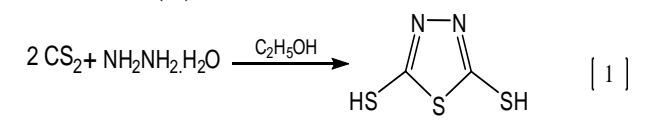

\section{Scheme (1): Chemical equation for the preparation of derivative (1)}

Compound (1) was characterized by its melting point and by (FT-IR, UV/Vis) spectrum. Melting point was recorded (159-161) ${ }^{0}$ C.The FT-IR spectrum of compound (1), showed a medium intensity band at $1620 \mathrm{~cm}^{-1}$ was due to $v$ $(\mathrm{C}=\mathrm{N}) .1273 \mathrm{~cm}^{-1}$ due to $v(\mathrm{C}=\mathrm{S})$ and showed the stretching vibration (2580) 
$\mathrm{cm}^{-1}$ due to $v$ (S-H thiol) and showed the absorption band at $(3251) \mathrm{cm}^{-1}$, due to $v$ (NH, thion form). This means that compound (1) can exist in the thiol and thion form.

The (UV/Vis) spectrum of compound (1), Figure (6), showed the absorption band at $331 \mathrm{~nm}$ for $\left(\mathrm{n}-\pi^{*}\right)$ resulting from a nonbonding electronic transitions of atoms heterogeneous (S, N) to thiadiazole ring and at $236 \mathrm{~nm}$ for $\left(\pi-\pi^{*}\right)$ belonging to the $(\mathrm{C}=\mathrm{N}$, azomethine group).

Compound (2) was prepared as shown in scheme (2).Some physical properties for this compound were listed in the Table (1).

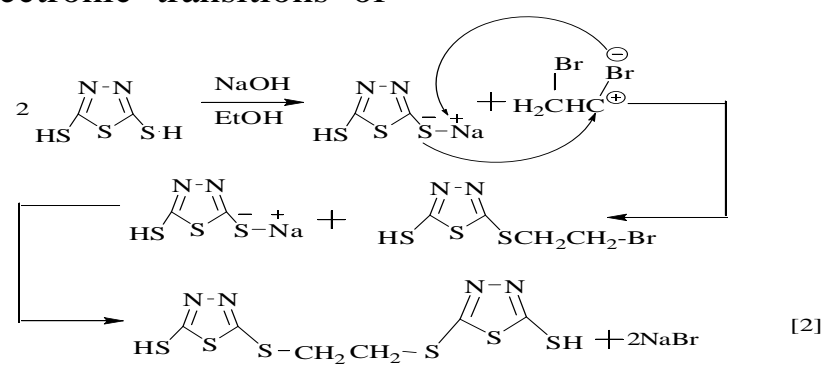

\section{Scheme (2): Mechanism steps for the preparation of derivative (2)}

Compound (2) was characterized by FTIR spectroscopy; FT-IR spectrum of compound (2), Figure (1), shows the absorption band at $(3205-3275) \mathrm{cm}^{-1}$, due to $v(\mathrm{NH}$, thion form) and $v(\mathrm{~S}-\mathrm{H}$ thiol) showed weak absorption band at (2569) $\mathrm{cm}^{-1}$. Bands at $(2962-2924) \mathrm{cm}^{-}$ ${ }^{1}$ were due to $v\left(\mathrm{CH}_{2}\right)$ groups that mean compound (2) can exist in the thiol and thion form. Band absorption at (1639) $\mathrm{cm}^{-1}$ was due to $\mathrm{v}(\mathrm{C}=\mathrm{N}$, azomethine group). Absorption band at (1141) $\mathrm{cm}^{-1}$ was due to $v(\mathrm{C}=\mathrm{S})$.

Compound (3) was prepared as shown in scheme (3). Some physical properties for this compound were listed in the Table (1).

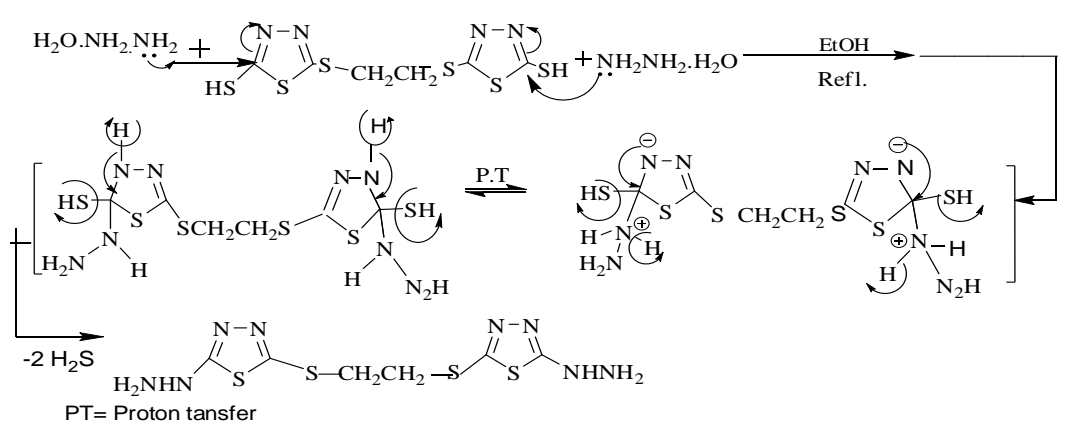

[3]

Scheme (3): Mechanism steps for the preparation of derivative (3)

Compound (3) was characterized by FTIR spectroscopy; FT-IR spectrum shows the absorption band at (3209) $\mathrm{cm}^{-1}$, due to $v(\mathrm{NH})$ and $v\left(\mathrm{NH}_{2}\right)$ bands showed at (3227-3305) $\mathrm{cm}^{-1}$, bands at (2962) $\mathrm{cm}^{-1}$ and (2824) $\mathrm{cm}^{-1}$, due to aliphatic $v$ $\left(\mathrm{CH}_{2}\right)$ group. Absorption band at (1643) $\mathrm{cm}^{-1}$ was due to $v(\mathrm{C}=\mathrm{N})$ stretching vibration. ${ }^{1} \mathrm{H}-\mathrm{NMR}$ spectrum of compound (3), Figure (9), showed characteristic signals at $\delta=(0.9$ $1.55) \mathrm{ppm}$ due to $\left(\mathrm{d}, 4 \mathrm{H},\left(2 \mathrm{CH}_{2}\right)\right)$ ,singlet signal at $\delta=(3.92-5.191) \mathrm{ppm}$ belongs to $\left(\mathrm{s}, 4 \mathrm{H},\left(2 \mathrm{NH}_{2}\right)\right), \quad(8.6-9.4)$ ppm due to $(\mathrm{s}, 2 \mathrm{H},(2 \mathrm{NH}))$ and at 2.50 ppm was due to the solvent DMSO-d6. Compound (4) was prepared as shown in scheme (4).Some physical properties for this compound were listed in the Table (1). 


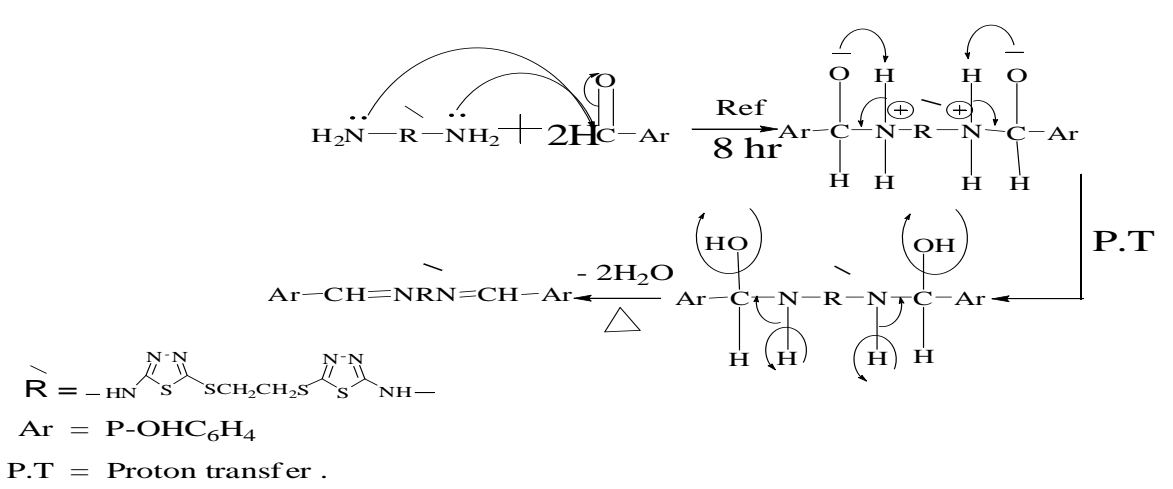

[4]

Scheme (4): Mechanism steps for the preparation of derivative (4)

Compound (4) was characterized by (FT-IR, UV) spectrum; The FT-IR spectrum of compound (4), Figure (2), showed the bands at (3286-3387) $\mathrm{cm}^{-1}$, due to $v(\mathrm{NH})$ and $v(\mathrm{OH})$ band showed at (3498-3444) $\mathrm{cm}^{-1}$, bands at (29692808) $\mathrm{cm}^{-1}$, due to aliphatic $v\left(\mathrm{CH}_{2}\right)$ group. Absorption bands at (1670-1600) $\mathrm{cm}^{-1}$ was due to $v(\mathrm{C}=\mathrm{N})$ stretching and (1273-1249) $\mathrm{cm}^{-1}$ absorption bands for phenolic group $v(\mathrm{C}-\mathrm{O})$.

The (UV/Vis) spectrum of compound (4) Figure (7) showed the absorption band at $(315 \mathrm{~nm})$ for electronic transitions $\left(\mathrm{n}-\pi^{*}\right)$ and at $(226 \mathrm{~nm})$ for transitions $\left(\pi-\pi^{*}\right)$.
${ }^{1} \mathrm{H}-\mathrm{NMR}$ spectrum of compound (4), Figure (10), showed characteristic signals at $\delta=(0.9-1.6) \mathrm{ppm}$ due to $\left(\mathrm{d}, 4 \mathrm{H},\left(2 \mathrm{CH}_{2}\right)\right)$, singlet signal at $\delta=(9.4-$ $9.6)$ ppm due to $(\mathrm{s}, 2 \mathrm{H},(2 \mathrm{NH}))$, at $\delta=$ (10.1-11.3) ppm for $(\mathrm{s}, 2 \mathrm{H},(2 \mathrm{OH}))$, at $\delta=$ (6.78-8.190) ppm belongs to $(\mathrm{m}, 10 \mathrm{H}$, $\left.2\left(-\mathrm{CH}-\mathrm{C}_{6} \mathrm{H}_{4} \mathrm{OH}\right)\right)$ and at $2.50 \mathrm{ppm}$ was due to the solvent DMSO-d6 . Elemental analysis for compound $\mathrm{C}_{20} \mathrm{H}_{18} \mathrm{~N}_{8} \mathrm{~S}_{4} \mathrm{O}_{2}: \quad[\mathrm{C}, \quad 45.28(45.589)$; $\mathrm{H}, 3.341(4.251) ; \mathrm{N}, 21.13(21.634) ; \mathrm{S}$, 24.15 (24.634)]

Compound (5) was prepared as shown in scheme (5).Some physical properties for this compound was listed in Table (1).<smiles>OCCSc1nnc(NN=Cc2ccc(O)cc2)s1</smiles>

Scheme (5): Chemical equation for the preparation of derivative (5)

Compound (5) was characterized by (FT-IR) spectrum; The FT-IR spectrum of compound (5), showed the bands at (3271-3236) $\mathrm{cm}^{-1}$, due to $v(\mathrm{NH})$ and $v$ $(\mathrm{OH})$ band showed at $(3363) \mathrm{cm}^{-1}$, bands at (2943-2931) $\mathrm{cm}^{-1}$, due to $v\left(\mathrm{CH}_{2}\right)$ group. absorption band at (1604) $\mathrm{cm}^{-1}$ was due to $v(\mathrm{C}=\mathrm{N})$. Also other absorption band appeared at $(1512) \mathrm{cm}^{-}$ 1 , was due to aromatic group $v(\mathrm{C}=\mathrm{C})$.
Elemental analysis for compound (5) $\mathrm{C}_{24} \mathrm{H}_{26} \mathrm{~N}_{8} \mathrm{~S}_{4} \mathrm{O}_{6} \quad \mathrm{C}, 44.3 \quad$ (44.5) ; $\mathrm{H}$, 4.0(4.951); N, $17.2(17.8) ; \quad \mathrm{S}, \quad 19.2$ (19.5)].

Compound (6) was prepared as shown in scheme (6).Some physical properties for this compound were listed in table (1).The suggested mechanism for this reaction is shown in the scheme (6) 


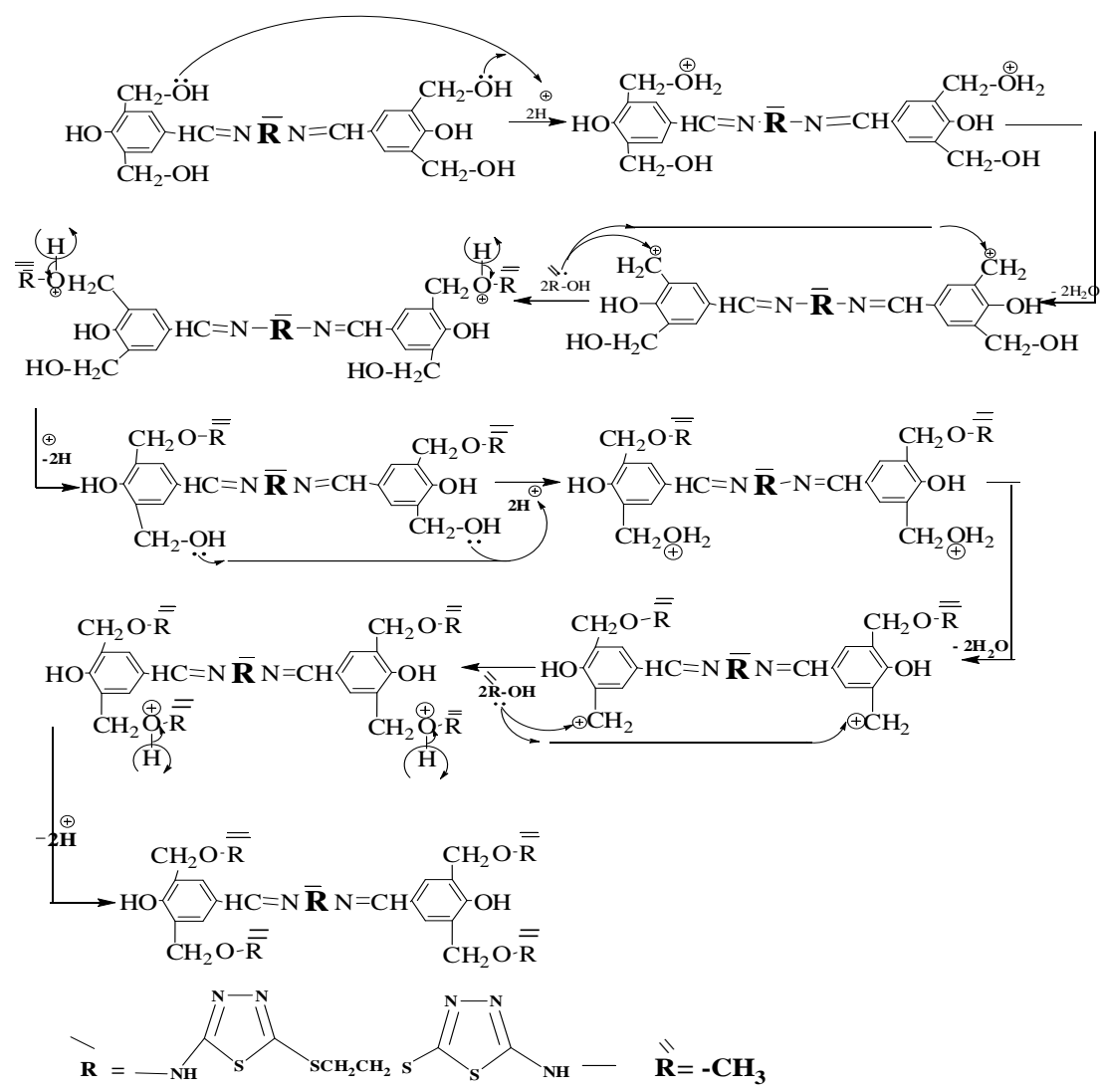

\section{Scheme (6): Mechanism steps for the preparation of derivative (6)}

Compound (6) was characterized by (FT-IR) spectrum; The FT-IR spectrum of compound (6), the appearance of new absorption bands at $(1165-1122) \mathrm{cm}^{-}$ ${ }^{1}$ was due to $v(\mathrm{C}-\mathrm{O}-\mathrm{C})$.
Compound (7) was prepared as shown in scheme (7).Some physical properties for this compound were listed in table (1).

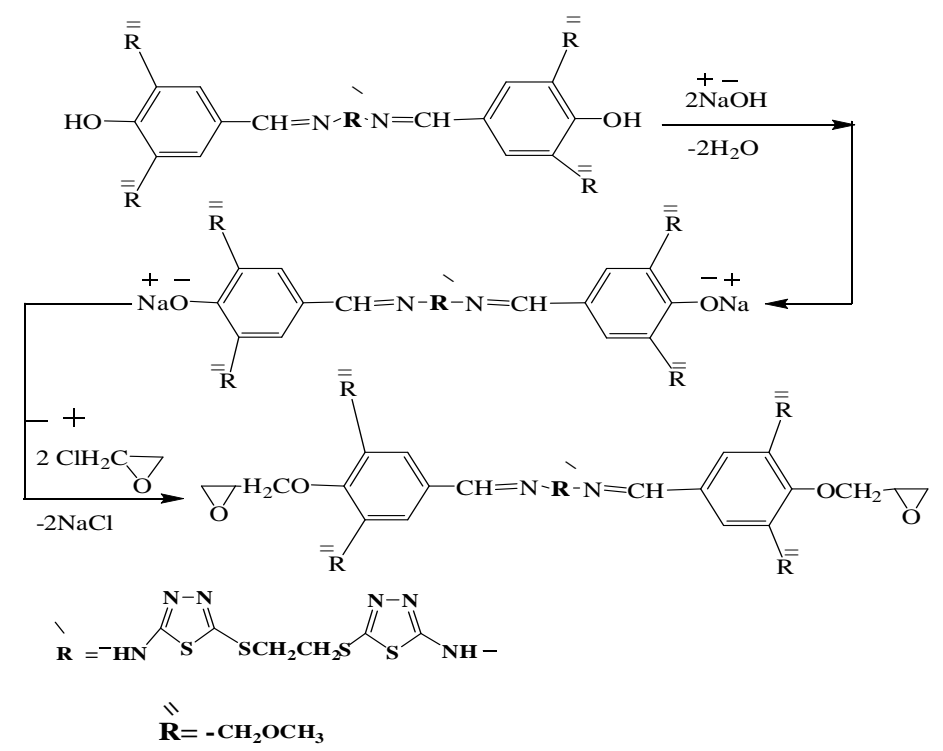

Scheme (7): Mechanism steps for the preparation of derivative (7) 
Compound (7) was characterized by (FT-IR) spectrum; The FT-IR spectrum of compound (7), Figure (3), showed the absorption bands at $(864-914) \mathrm{cm}^{-1}$, due to epoxy group, known as oxarine which attack on the phenolic $v(\mathrm{OH})$ group, absorption bands at $(1114-1172) \mathrm{cm}^{-1}$, due to $v$ (C-O-C) and strong bands (2947-2870) $\mathrm{cm}^{-1}$ for $v\left(\mathrm{CH}_{2}\right)$.

Compound (8) was prepared as shown in scheme (8). Some physical properties for this compound were listed in Table (1).

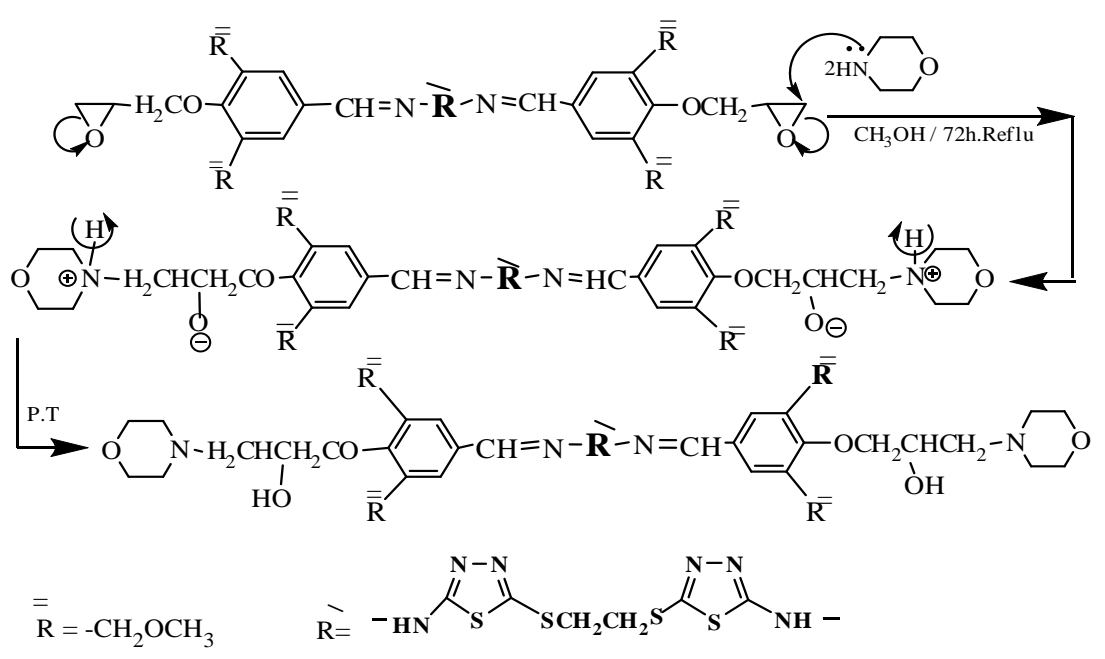

\section{Scheme (8): Mechanism steps for the preparation of derivative (8)}

Compound (8) was characterized by (FT-IR) spectrum; The FT-IR spectrum of compound (8), Figure(4), showed the absorption bands at (3398-3400) $\mathrm{cm}^{-1}$, due to $v(\mathrm{OH})$ and $v(1249) \mathrm{cm}^{-1}$ for $v$ (C-O).Absorption bands at (1134-1249) $\mathrm{cm}^{-1}$, due to $v(\mathrm{C}-\mathrm{O}-\mathrm{C})$ and strong bands (2943-2912) $\mathrm{cm}^{-1}$ for $v\left(\mathrm{CH}_{2}\right)$.

Compound (9) was prepared as shown in scheme (9). Table (3) shows the physical properties of epoxy resin derivatives with $\left(\mathrm{TiO}_{2}\right)$ pigment with ring opening.

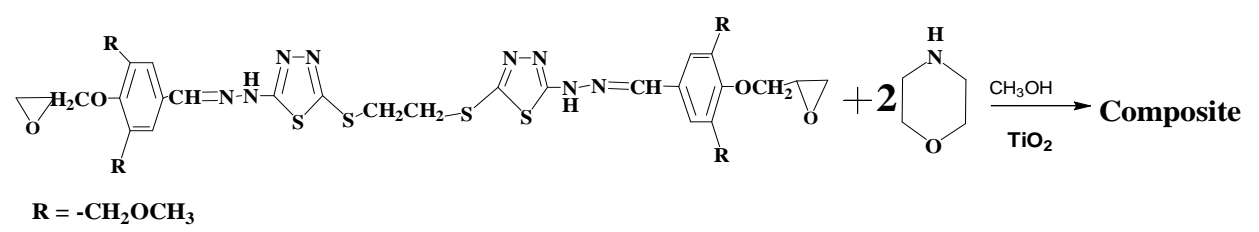

\section{Scheme (9): Chemical equation for the preparation of derivative (9)}

Compound (9) was characterized by (FT-IR) spectrum; The FT-IR spectrum of compound (9) Figure (5) showed the absorption band at $(3390) \mathrm{cm}^{-1}$ was due to $v(\mathrm{OH}),(1114-11168) \mathrm{cm}^{-1}$ was due to $v$ (C-O-C), and strong bands (29242858) $\mathrm{cm}^{-1}$ for $v \quad\left(\mathrm{CH}_{2}\right)$ showed characteristic FT-IR band at $(1604) \mathrm{cm}^{-}$ ${ }^{1}$, due to $v(\mathrm{C}=\mathrm{N})$.
By comparison between (FT-IR) spectrum of compound (9), Figure (5) with (FT-IR) spectrum of compound (8), Figure (4), showed the absorption similar bands which means that $\mathrm{TiO}_{2}$, wasn't changed from the structural formula of the compound (8),as shown in table (2) 
The $2^{\text {nd }}$ National Conference of Chemistry

The (UV/Vis) spectrum of compound $(9,8)$,Figure (8), showed the absorption bands at [ $(323 \mathrm{~nm}, 322 \mathrm{~nm}, 321 \mathrm{~nm}$ and $321 \mathrm{~nm})$ ]for electronic transitions $(\pi-$ $\left.\pi^{*}\right)$, also due to ratio $[40 \%, 30 \%, 10 \%$ and $5 \%$ of $\mathrm{TiO}_{2}$ and the highest value for the absorption was at (2.161),(1.878) due to ratio $40 \%, 30 \%$ of $\mathrm{TiO}_{2}$. And appeared medium value for the absorption at (1.562),(1.358), due to ratio $10 \%, 5 \%$ of $\mathrm{TiO}_{2}$. while the (UV/Vis) spectrum of compound (8)Figure (8), showed the absorption band at $(322 \mathrm{~nm})$ for electronic transitions $\left(\pi-\pi^{*}\right)$, and has been weakly in value of the absorption, which recorded (1.023), due to ratio $0 \%$ of $\mathrm{TiO}_{2}$.

Through the (UV/Vis) spectrum of compound $(9,8)$, Figure (8) showed the absorbance different which means that $\mathrm{TiO}_{2}$ improve of properties the epoxy resin through protecting it from UV ray, the addition of additives (inorganic like $\mathrm{TiO}_{2}$ ) to the epoxy resin will absorb ultraviolet light in the range (300-400) $\mathrm{nm}$ strongly [11], leading to nonabsorption of these rays by the epoxy molecules and active functional groups, as shown in table (5).

Table (1) Shows the physical properties of compounds (1-8) with formula.

\begin{tabular}{|c|c|c|c|c|c|c|c|c|c|c|c|}
\hline No. & $\begin{array}{l}\text { Molecular } \\
\text { Formula }\end{array}$ & $\begin{array}{l}\text { M.P } \\
{ }^{\circ} \mathrm{C}\end{array}$ & Colour & $\begin{array}{l}\text { Yield } \\
\%\end{array}$ & $\begin{array}{l}\text { Purify- } \\
\text { Solvent }\end{array}$ & No & $\begin{array}{l}\text { Molecular } \\
\text { Formula }\end{array}$ & M. $\mathrm{P}^{\circ} \mathrm{C}$ & Colour & $\begin{array}{c}\text { Yield } \\
\%\end{array}$ & $\begin{array}{l}\text { Purify- } \\
\text { Solvent }\end{array}$ \\
\hline 1 & $\mathrm{C}_{2} \mathrm{H}_{2} \mathrm{~N}_{2} \mathrm{~S}_{3}$ & $\begin{array}{l}159- \\
161 \\
\end{array}$ & $\begin{array}{c}\text { Light } \\
\text { yellow }\end{array}$ & 55 & $\begin{array}{c}\text { Distilled } \\
\text { water }\end{array}$ & 6 & $\mathrm{C}_{28} \mathrm{H}_{34} \mathrm{~N}_{8} \mathrm{~S}_{4} \mathrm{O}_{6}$ & Oily & Brown & 55 & THF \\
\hline 2 & $\mathrm{C}_{6} \mathrm{H}_{6} \mathrm{~N}_{4} \mathrm{~S}_{6}$ & $\begin{array}{l}200- \\
202 \\
\end{array}$ & White & 50 & Ethanol & 7 & $\mathrm{C}_{34} \mathrm{H}_{42} \mathrm{~N}_{8} \mathrm{~S}_{4} \mathrm{O}_{8}$ & Oily & $\begin{array}{l}\text { Brown- } \\
\text { yellow }\end{array}$ & 44 & THF \\
\hline 3 & $\mathrm{C}_{6} \mathrm{H}_{10} \mathrm{~N}_{8} \mathrm{~S}_{4}$ & $\begin{array}{l}230- \\
232 \\
\end{array}$ & Grey & 79 & Ethanol & 8 & $\mathrm{C}_{42} \mathrm{H}_{44} \mathrm{~N}_{8} \mathrm{~S}_{4} \mathrm{O}_{10}$ & Oily & Brown & 60 & Methanol \\
\hline 4 & $\mathrm{C}_{20} \mathrm{H}_{18} \mathrm{~N}_{8} \mathrm{~S}_{4} \mathrm{O}_{2}$ & $\begin{array}{l}155- \\
157 \\
\end{array}$ & Yellow & 77 & Ethanol & & & & & & \\
\hline 5 & $\mathrm{C}_{24} \mathrm{H}_{26} \mathrm{~N}_{8} \mathrm{~S}_{4} \mathrm{O}_{6}$ & Oily & $\begin{array}{c}\text { Dark } \\
\text { red }\end{array}$ & 52 & THF & & & & & & \\
\hline
\end{tabular}

Table (2): (FT-IR) spectrum data of compounds (1-9)

\begin{tabular}{|c|c|c|c|c|c|}
\hline No. & $v \mathrm{OH}$ & $v \mathrm{CH}_{2}$ & $v \mathrm{C}=\mathrm{N}$ & $v \mathrm{C}-\mathrm{O}-\mathrm{C}$ & Others \\
\hline 1 & - & - & 1620 & - & $\begin{array}{c}\text { v SH (2580), v C }=\mathrm{S}(1137) \\
v \mathrm{NH}(3251), v \mathrm{C}-\mathrm{S}-\mathrm{C}(698)\end{array}$ \\
\hline 2 & - & 2962- 2924 & 1639 & - & v $\mathrm{C}=\mathrm{S}(1141-1014)$, v C-S-C(597) \\
\hline 3 & - & $2962-2927$ & 1643 & - & $\begin{array}{c}\mathrm{vNH} \mathrm{NH} \mathrm{N}_{2}(3209-3448) \\
v \mathrm{C}-\mathrm{N}(1358), v \mathrm{~N}-\mathrm{N}(1431)\end{array}$ \\
\hline 4 & $\begin{array}{l}3498 \\
3444 \\
\end{array}$ & $2989-2808$ & 1600 & - & $\begin{array}{c}v \mathrm{C}=\mathrm{C}(1550), v \mathrm{C}-\mathrm{O}(1247) \\
v \mathrm{C}-\mathrm{H} \text { aromatic }(3100), v \mathrm{NH}(3387-3286)\end{array}$ \\
\hline 5 & 3363 & $2943-2931$ & 1604 & - & $\mathrm{vC}=\mathrm{C}(1512), \mathrm{vC}-\mathrm{O}(1253)$ \\
\hline 6 & 3460 & $2939-2930$ & $1604-1543$ & $1165-1122$ & $\begin{array}{c}\text { v C-H aromatic (3020) } \\
v \text { N-N (1442),v C-O (1234) }\end{array}$ \\
\hline 7 & $\begin{array}{l}3437 \\
3417\end{array}$ & $2947-2870$ & $1604-1658$ & $1114-1172$ & v C-H out of plane (659-756), \\
\hline 8 & $\begin{array}{l}3398 \\
3400\end{array}$ & 2943-2912 & 1604 & $1134-1249$ & $\begin{array}{c}\text { v C-H out of plane (732), v C-N(1354) } \\
\text { v C-O (1249) }\end{array}$ \\
\hline 9 & 3390 & $2927-2858$ & 1604 & $1138-1114$ & $v \mathrm{C}=\mathrm{C}(1508), v \mathrm{C}-\mathrm{O}(1253), v \quad \mathrm{~N}-\mathrm{N}(1454)$ \\
\hline
\end{tabular}

Table (3) Shows the physical properties of compound (9) with formula.

\begin{tabular}{|c|c|c|c|c|c|c|}
\hline Comp. No. & Molecular Formula & $\mathrm{TiO}_{2} \%$ & Colour & $\begin{array}{c}\text { The } \\
\text { mixing } \\
\text { ratio }\end{array}$ & $\begin{array}{c}\text { A gloss } \\
\text { degree at an } \\
\text { angle } 60^{\circ}\end{array}$ & $\begin{array}{l}\text { Plating } \\
\text { thickness }\end{array}$ \\
\hline 9 & $\mathrm{C}_{42} \mathrm{H}_{44} \mathrm{~N}_{8} \mathrm{~S}_{4} \mathrm{O}_{10}$ & $\begin{array}{c}(40 \%) \\
(30 \%) \\
(10 \%) \\
(5 \%)\end{array}$ & $\begin{array}{c}\text { Yellowish } \\
\text { white }\end{array}$ & $4: 1$ & $\begin{array}{l}1.2^{0} \\
1.3^{0} \\
1.7^{0} \\
1.9^{0}\end{array}$ & $\begin{array}{l}100-500 \\
\text { Micron }\end{array}$ \\
\hline
\end{tabular}


The $2^{\text {nd }}$ National Conference of Chemistry

Table (4): Shows the elemental analysis (C.H.N.S) of the derivatives $(4,5)$

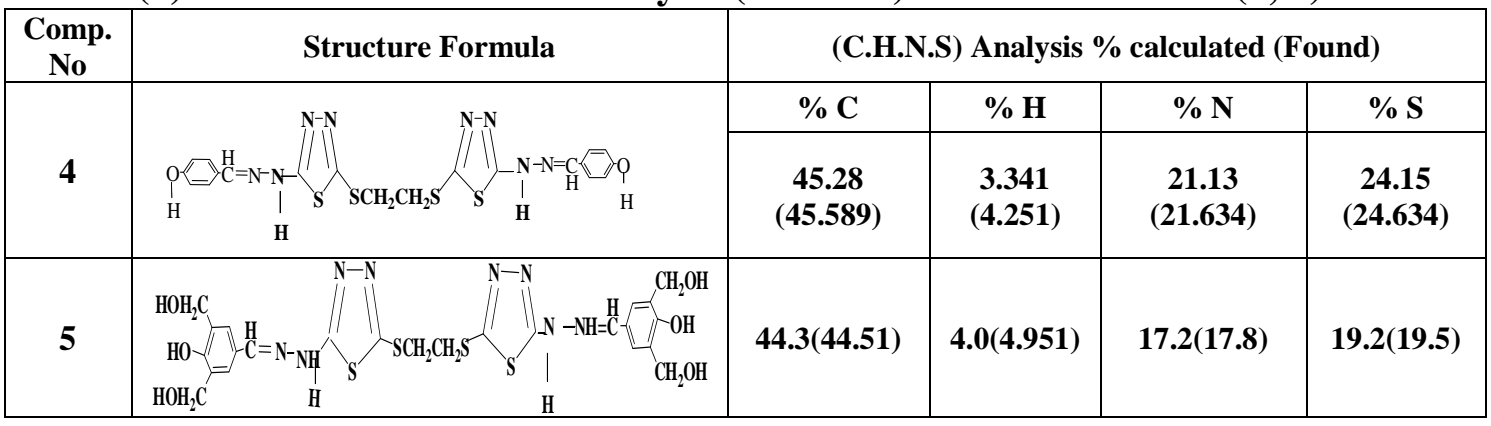

Table (5): (UV/ Vis) spectrum data of the compounds $(9,8)$

\begin{tabular}{|c|c|c|c|c|c|c|}
\hline \multirow{2}{*}{$\begin{array}{c}\text { Comp. } \\
\text { No. }\end{array}$} & \multirow[b]{2}{*}{ Molecular Formula } & \multirow[b]{2}{*}{ TiO2 \% } & \multicolumn{4}{|c|}{ (UV/ Vis) spectrum } \\
\hline & & & $\begin{array}{c}\lambda \max \\
\mathbf{n m}\end{array}$ & Abs & $\begin{array}{c}\lambda \max \\
\mathbf{n m}\end{array}$ & $\begin{array}{c}\text { Transmittance } \\
\text { (T \%) }\end{array}$ \\
\hline 8 & $\mathrm{C}_{42} \mathrm{H}_{44} \mathrm{~N}_{8} \mathrm{~S}_{4} \mathrm{O}_{10}$ & B1 (0\%) & 322 & 1.023 & 322 & 2.250 \\
\hline \multirow{4}{*}{9} & \multirow{4}{*}{$\mathrm{C}_{42} \mathrm{H}_{44} \mathbf{N}_{8} \mathrm{~S}_{4} \mathrm{O}_{10}$} & B2 $(5 \%)$ & 322 & 1.358 & 323 & 1.558 \\
\hline & & B3 $(10 \%)$ & 323 & 1.562 & 323 & 1.0 \\
\hline & & B4 (30\%) & 323 & 1.878 & 323 & 0.6 \\
\hline & & B5 (40\%) & 323 & 2.161 & 323 & 0.42 \\
\hline
\end{tabular}

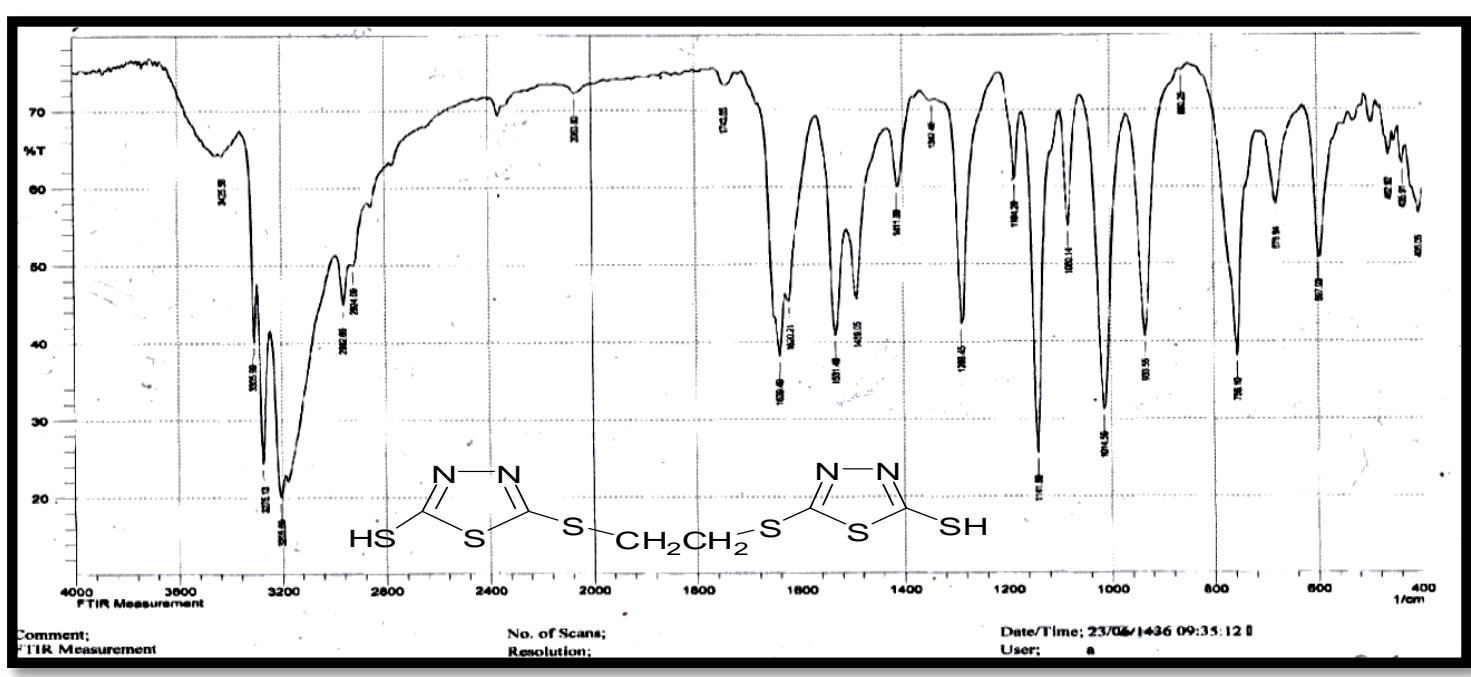

Fig.(1): FT-IR spectrum of compound (2)

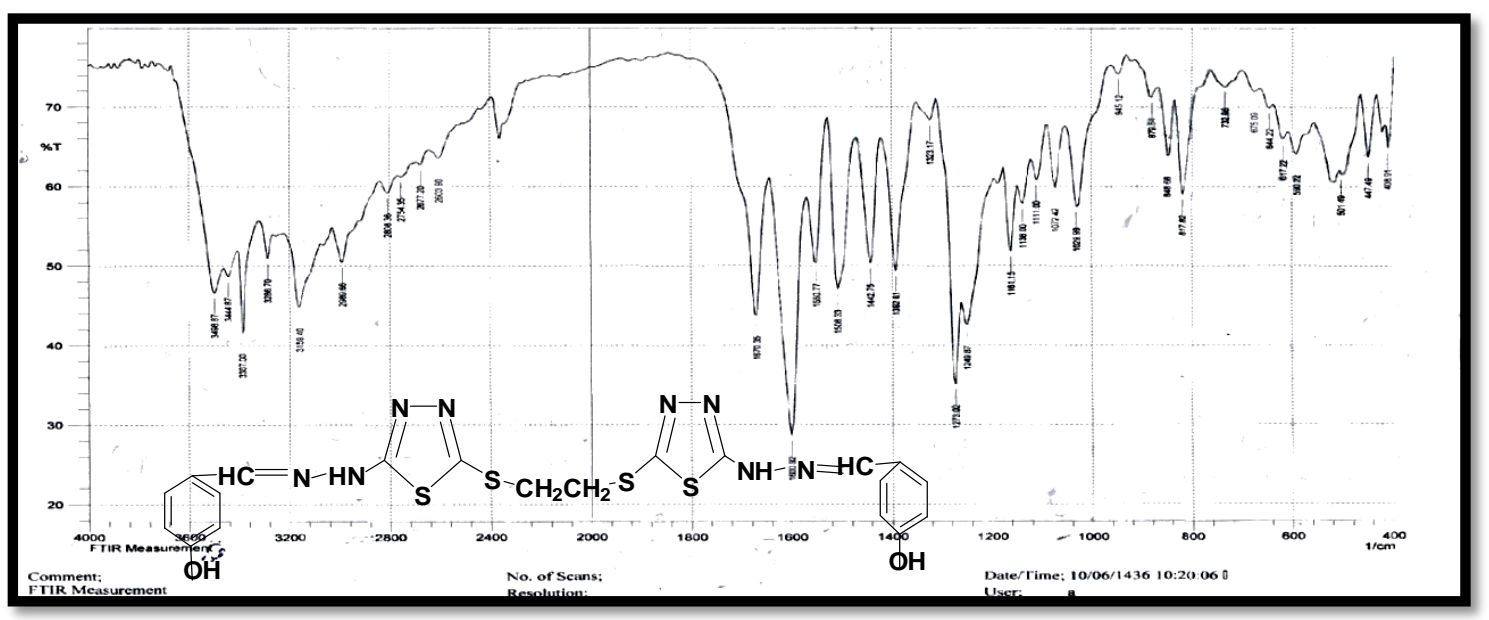

Fig. (2): FT-IR spectrum of compound (4) 


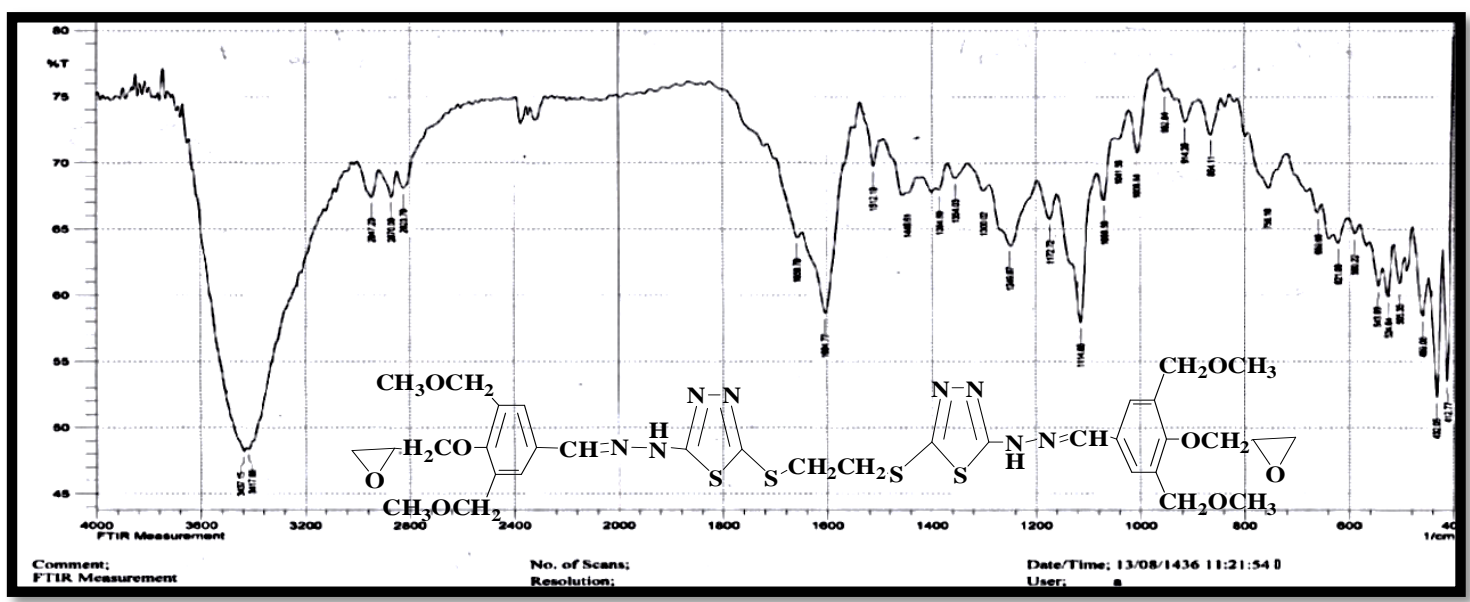

Fig. (3): FT-IR spectrum of compound (7)

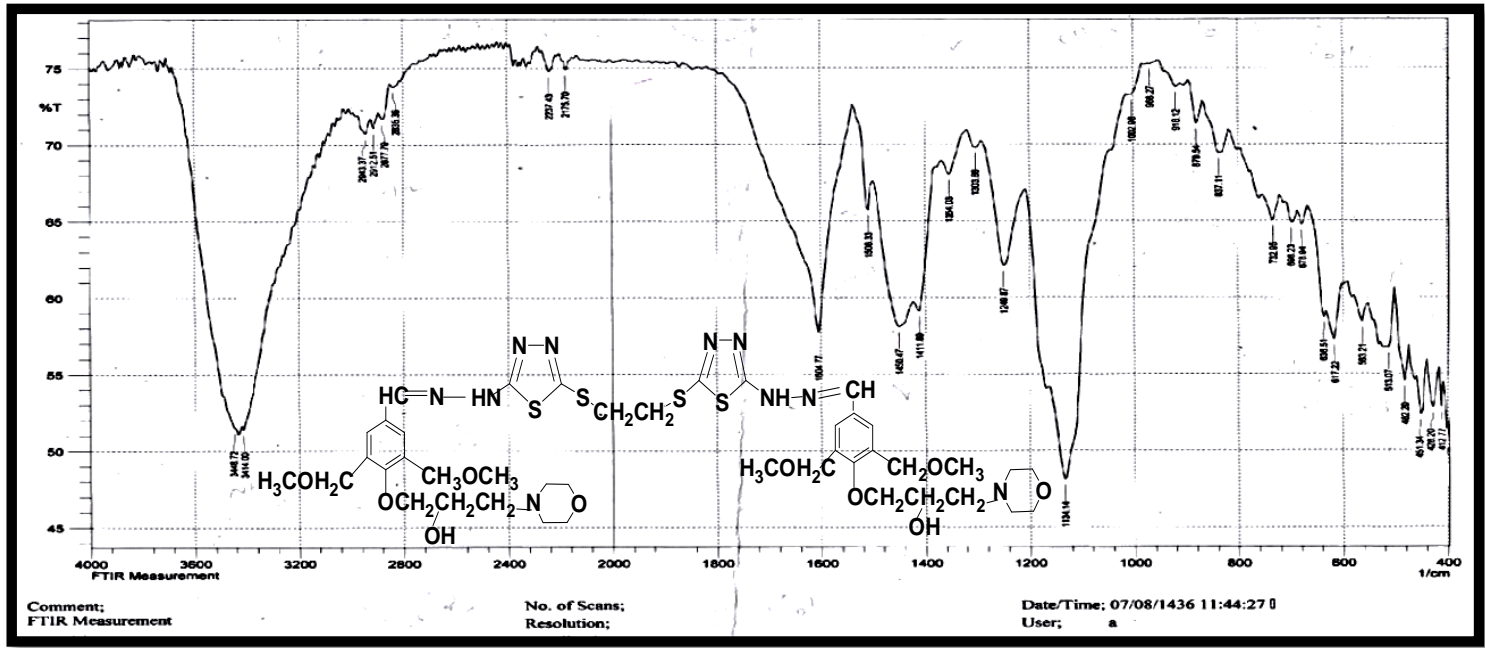

Fig. (4): FT-IR spectrum of compound (8)

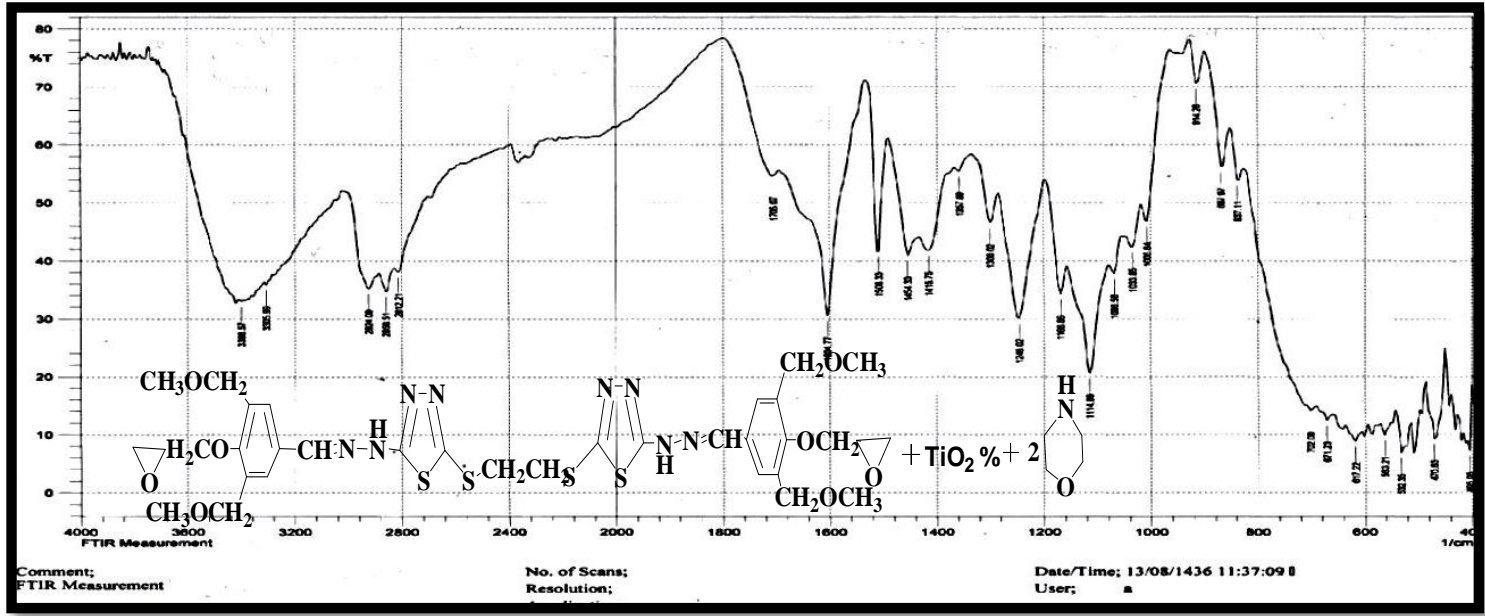

Fig. (5): FT-IR spectrum of compound (9) 


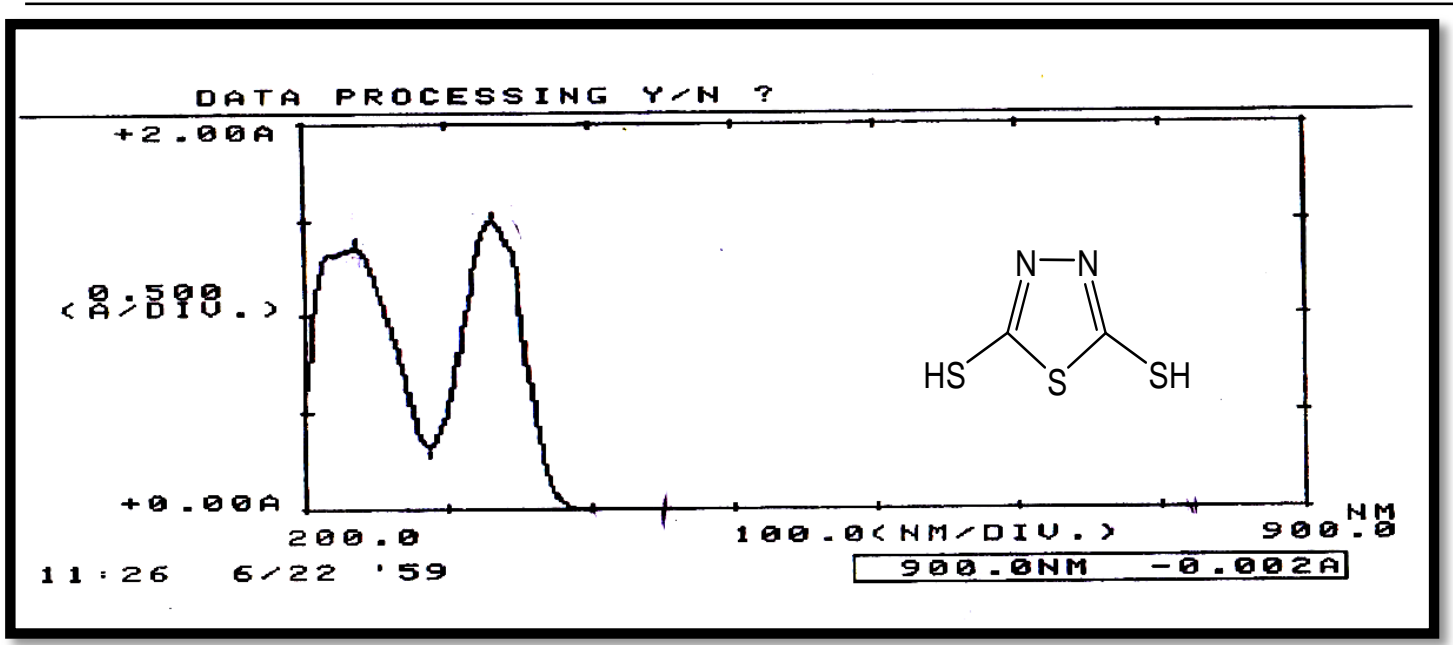

Fig. (6): UV spectrum of compound (1)

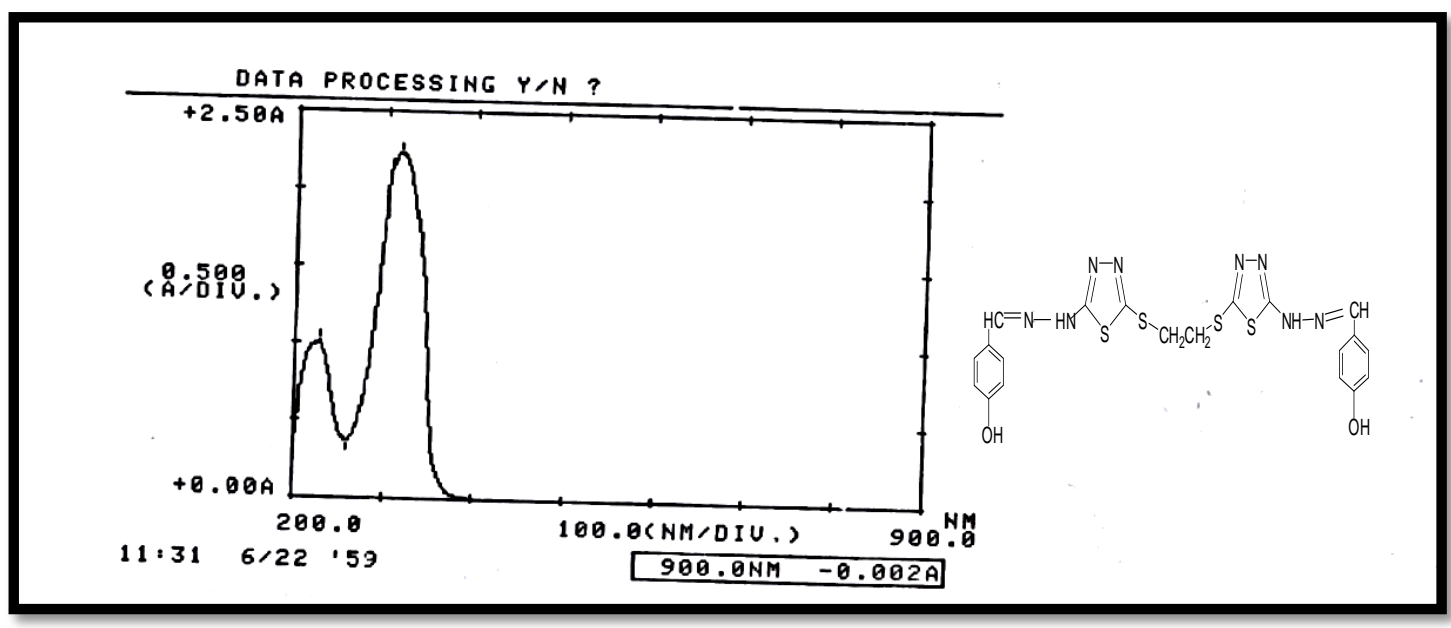

Fig. (7): UV spectrum of compound (4)

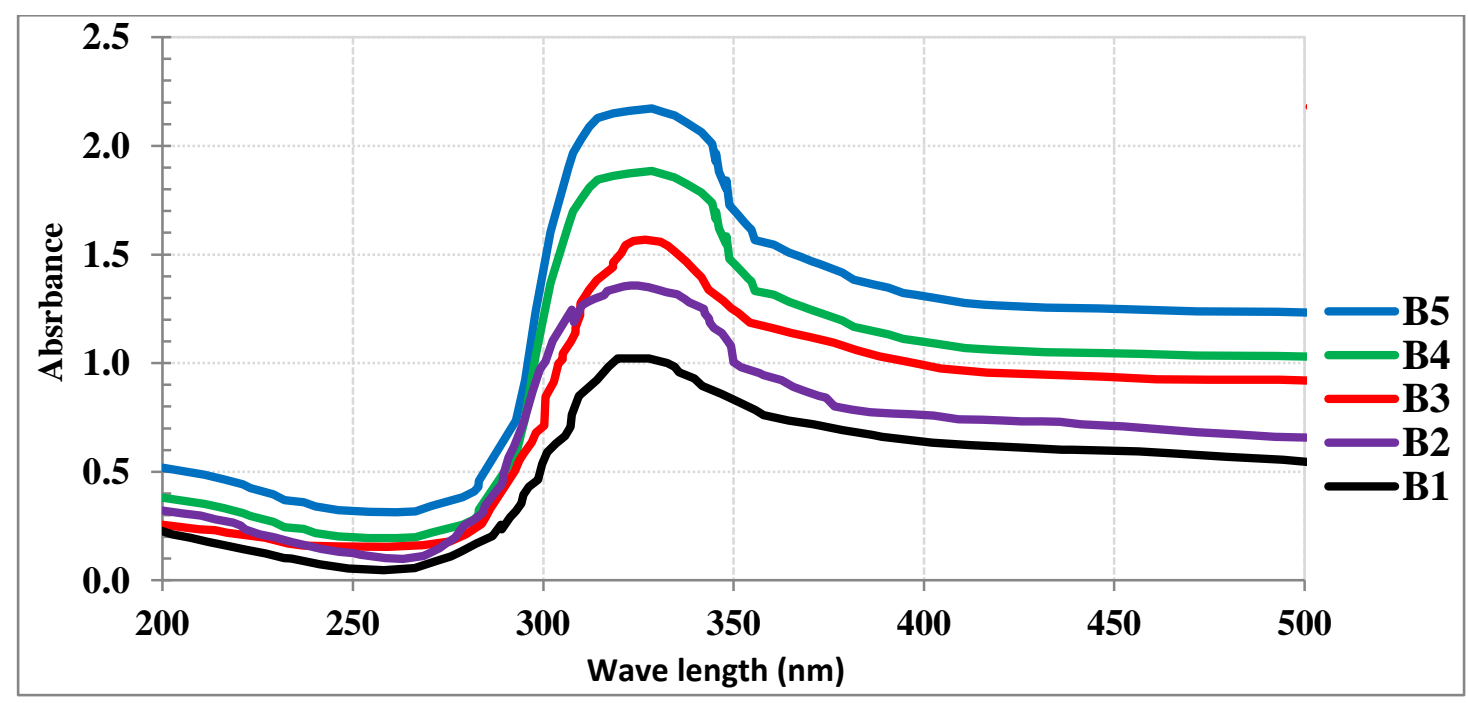

Fig. (8): shows the variation of Absorbance of the compound $(9,8)$ 


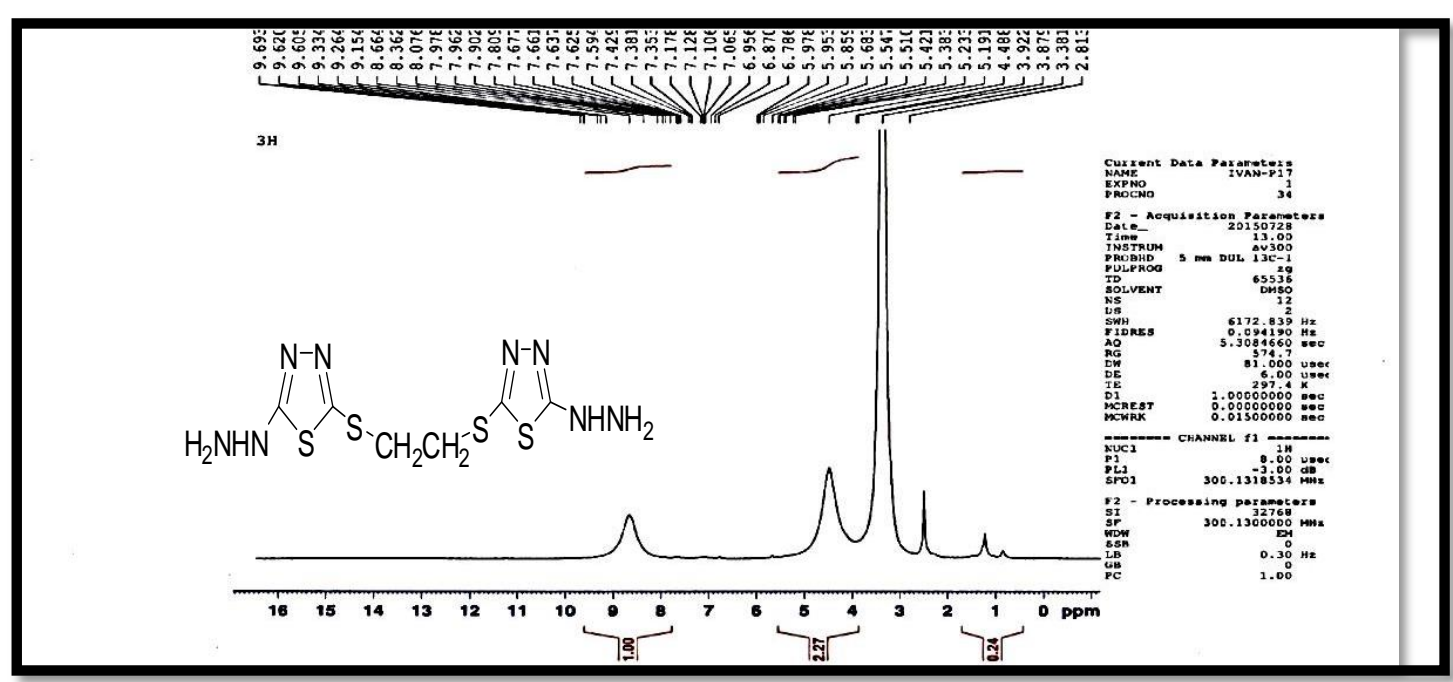

Fig. (9): ${ }^{1} \mathrm{H}-\mathrm{NMR}$ spectrum of compound (3)

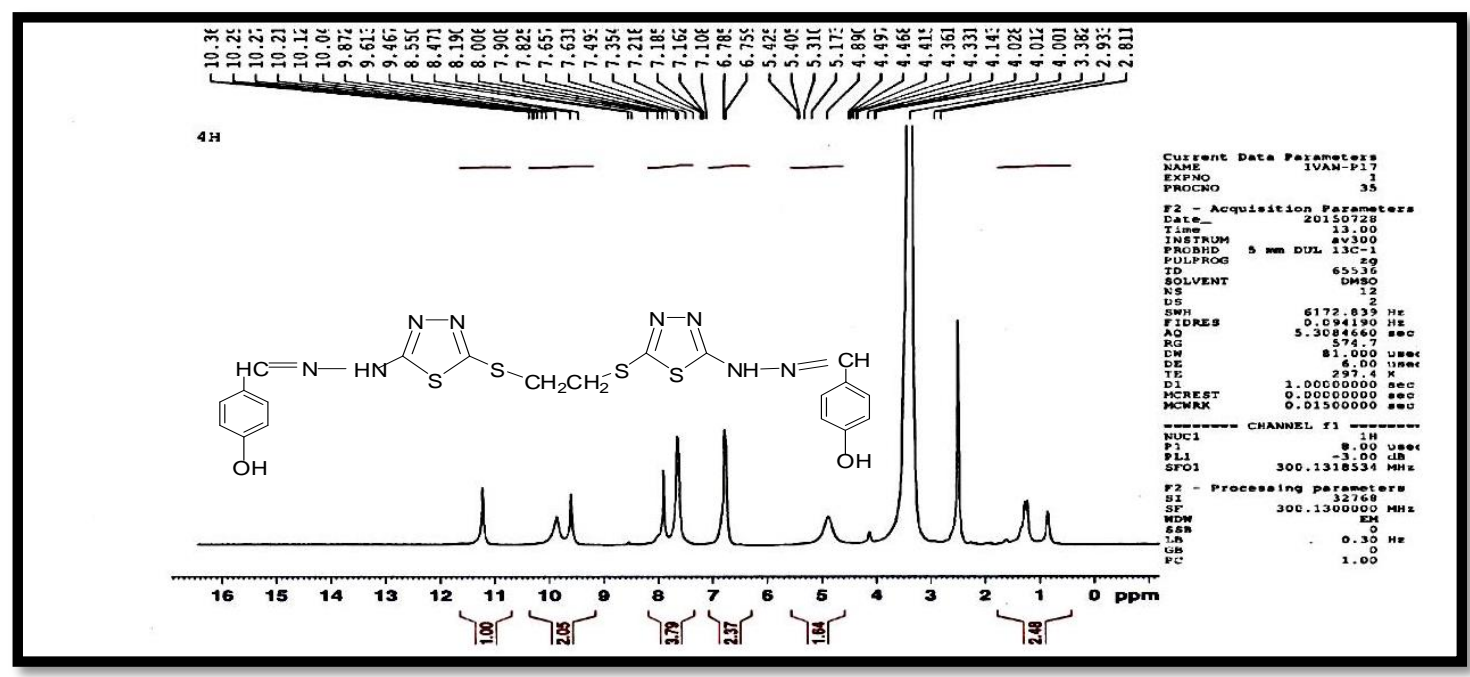

Fig. (10): ${ }^{1} \mathrm{H}-\mathrm{NMR}$ spectrum of compound (4)

\section{Conclusion:}

During the preparation of the new derivatives from the basic component, (2, 5-dimercapto-1, 3, 4- thiadiazole), the epoxy and methylol derivatives have been prepared,and these have great importance because they are used, widely, as industrial applications especially paints and glue industry.

\section{References:}

[1] Gupta, J.; Yadav, R.; Dudhe, R. and Sharma, P. K. 2010. Recent advancements $\mathrm{i}$ in the synthesis and pharmacological evaluation of substituted 1, 3, 4-thiadiazole $\mathrm{d} d$ derivatives. Int. J. Pham. Tech. Res.,2(2): 1593-1507.

[2] Salman, S. M. 2007. Synthesis of new 2-amino-5 - mercapto - 1, 3 ,4 thiadiazole derivatives and polymerized some of them. M.Sc. Thesis, University of Baghdad.

[3] Aoras, A. 2013. Synthesis and evaluation of biological activity of new heterocyclic compounds derived from 2- amino -5- mercapto -1,3,4 thiadiazole. M. Sc. Thesis, College of Science, University of Mustansiriya.

[4] Sonwane, S. K. and Srivastava. S. D. 2008. Synthesis and biological significance of 2-amino-4-phenyl -1, 
3-thiazole derivatives. Proc. Nat. Acnd. Sci. India. 78A (2): 129-136.

[5] Samir, F.; Barsoum, H. and Adel, A. M. 2012. Synthesis and antiinflammatory activity of some pyrazole derivatives, Med. Chem. Res., 21:1722-1733.

[6] Yang, W.; Sun, Z. L. and Z. Ma, 2002. The Rapid synthesis of Schiff base without solvent under microwave irradiation. Chin. Chem. lett, 13(1) : 3-6.

[7] Martin, R.W.1956.The chemistry of phenolic resins. Wiley and Sons, New York, 69,Iss. 6:189-212.

[8] Lee, H., and Nevile, K. 1967. Hand book of epoxy resins, Mc Grow Hill, $2^{\text {th }}$ ed, New York University.899.

[9] Sharma, p.; Bhanot, v. k. and Hundal, H. S. 2013. Rrsearch work on fiber glass wool reinforced and epoxy matrix composite material .Int. J. Mec . Eng. and Rob .Res 2,(2):106119.

[10] Monteiro, S. N. and d"Almeida, J.R. 1997.The role of the resin matrix/ hardener ratio on the mechanical properties of low volume fraction epoxy composites. Adv. Perf. Material., 4(3): 285-295.

عليوي، صلاح محسن. (2002-205). التجزئة [11)

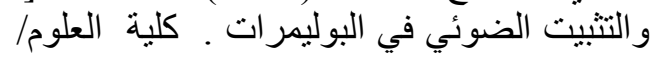
الجامعة المستتصرية، 71-70 التية

[12] Wang, D.L.; Sung. L. and Craig, B. 2004. Effect of $\mathrm{TiO}_{2}$ pigment type on the UV degradation of filled coatings report. JCT Coatings Tech. 1(5):32-38.

[13] Mustafa, M. A. and Alaa, H. J. 2012. Synthesis, characterization and evaluation of biological activity of new heterocyclic compounds containing 1, 2, 4- triazole

and 1,3,4- thiadiazole Rings. J. Appl. Sci. and Tec.2(10):155-156.

[14] Hasan, E. M. 2010. Synthesis of new 2-amino -5- mercapto-1,3,4thiadiazole derivatives. M.Sc. Thesis, College of Science, University of Baghdad.

[15] Ahmed, N. H. 2015.Synthesis of 2,5-disubstituted-1,3,4-thiadiazole derivatives and study of their biological activity. M. Sc. Thesis, College of Science, University of Mustansiriya.

[16] Sunny, A.; Gupta, A. and Hemraj, j.2012.Synthesis, biological activities and chemistry of thiadiazole derivatives and Schiff bases. Asian J Pharm Clin Res, 5, Issue 3:199-208.

[17] Adam. G. A. 2001. Chemistry and technology of methylolic resins; their derivative and IPNs. Nati. J. of Chem., 1: 131-157.

[18] Hasan, I. M. M. and Saleh, S. H. 2013. Synthesis and characterization of some new phenolic Schiff bases derivatives. J. Baghdad for Sci.,10 (2): 378

[19] Clayton, A. and yoshioxii, T.1973.Epoxy resins; Chemistry and technology. $2^{\text {th }}$

ed, 801 .

[20] AL- Zubiady, S. F. 2012. Synthesis and characterization of derivatives based on 4,-dimercaptobiphenyl. J .Baghdad for Sci.9 (4):704.

[21] Huang,K. S.; Nien, Y. H. ; Chen, J. S.; Shieh, T. R. and Chen, J.W. 2006. Synthesis and properties of epoxy / $\mathrm{TiO}_{2}$ composite materials. Polymer composites, 27(2): 195-200. 


\section{تحضيروتثخيص مركبات حلقية غير متجانسة جديده من 5،2، ثنائي مركبتو

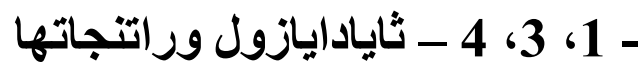

***راء عبد الستار اسماعيل بان ذنون اسماعيل ش* شاضل الزبيدي

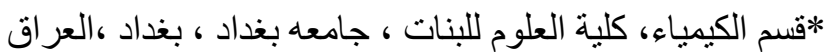

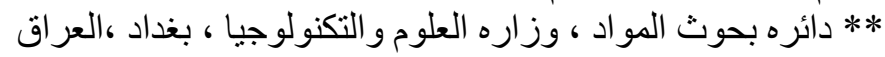

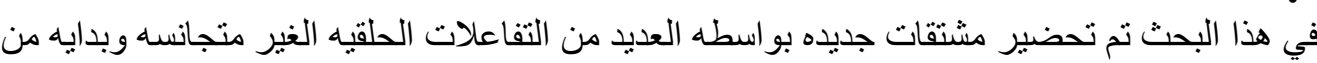

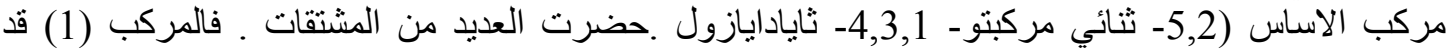

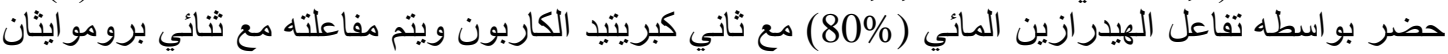

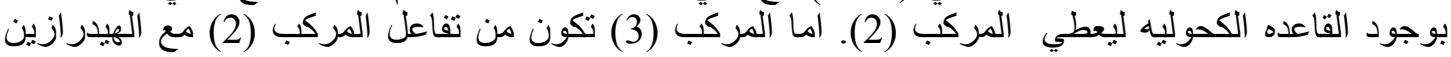

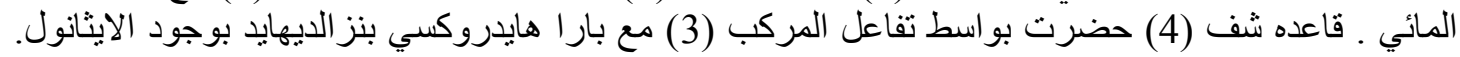

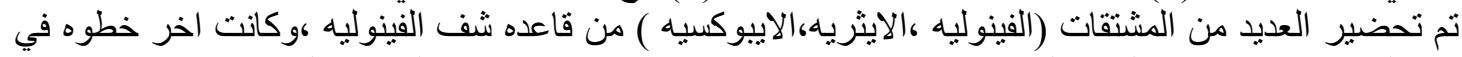

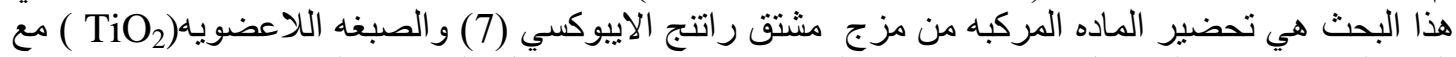

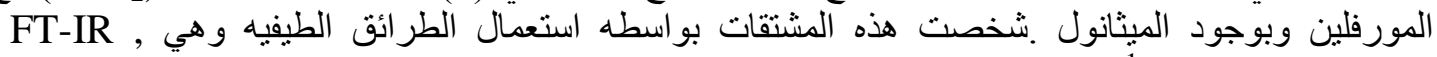

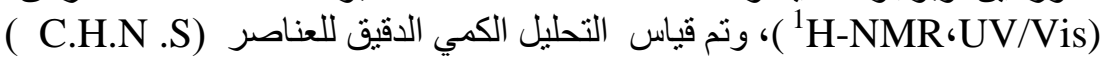
الكلمات المفتاحيه : تحضير ، مركبات حلقيه الجديده ، 5,2- ثنائي مركبتو - 4,3,1- ثايادايازول ، ر اتتجاتها 